\title{
Effect of Government Agriculture Investment on Economic Growth in Sub-Saharan Africa: Evidence from Nigeria, South Africa and Ghana
}

\author{
Dr. Michael C. Obialor \\ Department of Banking and \\ Finance, Chukwuemeka \\ Odumegwu Ojukwu University, \\ Igbariam Campus, Anambra State, \\ Nigeria
}

\author{
Prof. Samuel M. Nzotta \\ Department of Financial \\ Management Technology, \\ Federal University of Technology, \\ Owerri, Imo State, \\ Nigeria
}

\author{
Chinedu Blessing-Mike Obialor \\ Department of Banking and \\ Finance, Legacy University, \\ Okija, Anambra State, \\ Nigeria
}

\section{ABSTRACT}

This study examines the effect of government agriculture expenditure on economic growth of three Sub-Sahara African (SSA) countries of Nigeria, South Africa and Ghana from 1980 to 2013. The objective is to analyze the growth effect of three agriculture expenditure variables of Agricultural Raw Material Import (ARMI), Agricultural Machinery (AMACH), and Real Interest Rate (RIR) on the economies of these countries; Secondary data are sourced from World Development Indicators (WDI) online Database and analyzed, using Co-integration techniques and Vector Error Correction mechanism (ECM), at $1 \%$ and $5 \%$ significance levels. The results indicate that none of the three agriculture proxy variables show significant positive effect on growth but rather insignificant positive effect implying that government agriculture financing has a weak effect on growth in SSA. This study concludes that, the SSA countries' economies still exhibit the potentials for enhanced economic growth in the long run judging from the VECM test results. The study recommends increased budgetary allocations for importation of necessary agricultural equipment and raw materials, as well as tackle the various identified problems of the sector to enhance economic growth.
Keywords: Government Agriculture Expenditure, Economic Growth, Cointegration, Vector Error Correction Model, Sub-Sahara African Economies

\section{INTRODUCTION}

\section{Background to the Study}

The incidence of market failures and low level of development in some social service sectors, often necessitates public resource allocation. These conditions apply to agriculture in Sub-Saharan Africa where, a relatively small amount of public funds is spent on agriculture in the region (Morgues, Bingxin, Fan, McBride, 2011). Generally, the effect of government provisions on agricultural productivity is not yet clear from previous studies (Reinikka \& Svensson 2002), Allen \& Qaim (2012)

However, Nchuchuwe and Adejuwon(2012) posits that Agriculture contributes immensely to the African economy in various ways; in the provision of food for the increasing population; supply of adequate raw materials to a growing industrial sector; a major source of employment, generation of foreign exchange earnings; provision of market for the products of the industrial sector among others. Agricultural growth is seen as an important step towards economic development and transformation 
and so critical to achieving global poverty reduction targets. It is still the most important productive sector in most low income countries, often in terms of its share of GDP and almost always in terms of the number of people it employs (International Development Association, IDA, 2009).

A study on the role of agriculture in five African countries reveals that in many African countries, only agriculture has sufficient scale to increase economic growth significantly over the foreseeable future. Agricultural growth is also more effective at reducing poverty even in countries that may have the potential for industrial growth driven by rich mineral resources. Loto (2011) posits that improvement in agricultural productivity and food security along with provision of better infrastructures (health, housing and education services), results in better standard of living which is evidence of economic growth.

Agricultural sector, under Maputo Declaration 2003, therefore, requires African Governments to increase expenditure on agricultural sector to at least 10 percent of the national budgetary resources (New partnership for Africa's Development (NEPAD 2011). Equally, the World Development Report (WDR) 2008, "Agriculture for Development", calls for greater investment in agriculture in developing countries. The report went further to warn that the millennium development goals (MDG'S) of halving extreme poverty and hunger by 2015 will not be realized unless the sector is placed at the centre of the development agenda especially in view of the persistent neglect and declining investment in the sector. The report pointed out that agriculture and rural sectors have suffered from neglect and underinvestment over the past 20 years. It further disclosed that, while 75 percent of the world's poor live in rural areas, only 4 percent of official development assistance (ODA) goes to agriculture in developing countries in Sub-Saharan Africa (SSA). Public spending for farming is also 4 percent of total government spending yet, the sector is taxed at relatively high levels (WDR) 2008).

The World Bank group therefore, is advocating a new "Agriculture for Development" agenda, based on its belief that, for the poorest people, GDP growth originating in Agriculture is about 4 times more effective in reducing poverty, than GDP growth originating outside the agricultural sector (WDR, 2008.)
Morgan and Solarz (1994), disclosed that changes in agricultural productivity in many African countries can be achieved through agricultural reforms and advanced inputs. Anderson, de Renzio and Levy (2006) regretted that despite the number of programs implemented to increase public investment in developing countries, the desired effect of these programs on poverty, had not been had and attributed this program ineffectiveness to corruption, insufficiency of funds, improper targeting and a number of other reasons. According to Robert B. Zoellick, (World Bank group President), Agriculture should be given more prominence across board and advised that countries globally, must deliver on vital reforms, civil society groups such as farm organizations must be involved in setting the agricultural agenda. Agriculture can offer pathways out of poverty if efforts are made to increase productivity in the staple foods sectors, connect small holders to rapidly expand high value horticulture, poultry, aquaculture and dairy markets, and generate jobs in the rural non-farm economy (WDR, 2008).

This study therefore, examines the effect of government investment in agriculture in SSA and to determine its effect on economic growth in the region.

\section{The Statement of the Problem}

There has been a continued debate among scholars on public expenditure-economic growth nexus, which has given rise to conflicting and inconsistent results.. For instance, in the Keynesian model, it is argued that government budgetary expansion (fiscal policy intervention in the economy), helps to improve the failure that might arise from the inefficiencies of the market. Government spending augements aggregate demand, and through multiplier effect stimulates economic growth.(Ebiringa \& Charles-Anyaogu 2010). This view is in contrast with the position of the neoclassical who held the view that government consumption expenditure crowds out private investment, hampers economic growth in the short run and diminishes capital accumulation in the long run. (Diamond 1989).

However, Al-Yousif (2000), Ranjan and Sharma, (2008), Cooray (2009) in line with the Keynesian model, concluded that when government increases expenditure on socio-economic and physical infrastructure sit contributes positively to economic growth. However, Ram (1996) found a stronger 
positive relationship existing between public expenditure and economic growth in lower income countries than in higher income countries. The reasons adduced for this scenario is that sometimes government activities produce misallocation of resources and impede the growth of national output, as is the case with some politicians and governments in power who engage in unproductive projects.

The fear is that such inconsistencies may have adverse effect on policy-making in the different economies and therefore need to be addressed to avoid the use of blanket policy recommendations for all economies. The contrasting views and inconsistencies of the extant studies could be attributed to the cross-national nature of some of the previous studies which sometimes involve pooling of data. However, Pessaran an \& Smith (1995) pointed out that pooling of data often result in inconsistent estimates and that the inconsistency does not disappear even when the size of the cross-section and that of the time period is large.

Since each country is unique, application of crossnational results to policy formulation for each country may therefore, be misleading. The corrective approach therefore, is to avoid pooling of data technique and rather use country specific data and perform separate analyses for each country and to make recommendations based on the observed peculiarities of each economy. Against this backdrop the present study therefore, instead of pooling of data, uses country-specific data of the selected variables for each country to analyse separately the growth effect of government provision in Agricultural Productivity on economic growth in Sub-Saharan Africa, taking evidence from Nigeria, South Africa and Ghana. The recommendations of the study are equally based on the observed peculiarities of each country to avoid blanket policy effect; meaning that a common agricultural policy may not be suitable for all the countries since each country is unique.

\section{Objectives of the Study}

The main objective of this study is to investigate the effect of government expenditure in agriculture, on economic growth in Sub-Sahara Africa (SSA).taking evidence from Nigeria, South Africa and Ghana.The specific objectives include; determining the effect of the respective proxy variables of government agriculture expenditure (AMACH, ARMI, and RIR) on economic growth in Sub-Saharan Africa. The formulated null hypothesis says that the proxy variables of government agriculture expenditure have no statistical effect on economic growth in SSA

\section{THEORETICAL FRAMEWORK \\ AND EMPIRICAL}

The theory of this study focuses on explaining the effect of government expenditure on economic growth in Sub-Sahara Africa. This explanation is based on the Keynesian hypothesis. Keynes in his publication, 'The general theory of employment, interest and money' in 1936, asserted that a key factor that could account for an economy's stagnation and unemployment was the deficiency of aggregate effective demand. His view was that the solution to the problem of economic stagnation rested on the expansion of aggregate demand through massive increase in government expenditure. Thus, in the Keynesian model, public expenditure is an exogenous factor and policy instrument for increasing national income. The Keynesian macroeconomic theory generally assumes that increased government expenditure tends to lead to high aggregate demand and in turn rapid economic growth. The theory hinges on the belief that public spending contributes to economic growth because when government increases consumption expenditure it will lead to increase in employment, profitability and investment through multiplier effects on aggregate demand. Therefore, government expenditure augments aggregate demand (Ebiringa \& Charles-Anyaogu 2012). Hence, the Keynesians strongly believe on the efficacy of fiscal measures to control the economy through aggregate demand, which became necessary due to the prevalence of market failure.

Contrary to this view, the neoclassical growth models argue that fiscal policy does not have any effect on the growth of national output (Abu \& Abdullahi 2010). The neoclassicals claim that higher government expenditure may slow down overall performance of the economy on the grounds that by increasing rising expenditure, government may increase taxes or borrowing. Consequently, higher income taxes may discourage individuals from working for long hours or even searching for jobs, which may result in reducing income and aggregate demand. Similarly, higher profit tax has the tendency to increase production 
costs and reduce both investment expenditure and profitability of firms. The basis for the argument is that when government increasingly borrows from banks to finance expenditure, it will compete (crowdsout) away the private sector thus reducing private investment. Furthermore, corruption, and activities of some politicians and government officials sometimes result in expenditure and investment in unproductive projects or in goods which the private sector can produce more efficiently. Thus government activities produce misallocation of resources and impede the growth of national output.

Furthermore, although Adolph Wagner in his Theory of Increasing State Activities admits that there is a functional relationship between government expenditure and economic growth, but causality runs from economic growth to government expenditure, as against Keynesian proposition that government expenditure causes economic growth. Hence, for Keynes government expenditure is exogenous to economic growth while for Wagner government expenditure is endogenous.

However, there are some extant studies which tend to lend credence to the Keynesian hypothesis; Abdullah (2000) carried out a study on the relationship between government expenditure and economic growth in Saudi Arabia and reported that size of government expenditure is very important in the performance of the economy. He however advised that government should increase its spending on infrastructure, social and economic activities. In addition, government should encourage and support the private sector to accelerate economic growth. Also Olugbenga \& Owoye (2007) investigated the relationship between government expenditure and economic growth for a group of 30 OECD countries from 1970 to 2005. The results show both a long run relationship and unidirectional causality from government expenditure to economic growth for 16 out of the 30 countries, thus supporting the Keynesian hypothesis. On the other hand, causality runs from economic growth to government expenditure in 10 out of the 30 countries, thus confirming Wagner's law. Furthermore, Liu Chih, Hsu, and Younis (2008) studied the relationship between government expenditure and economic growth for the US data from1974 to 2002. The Causality results revealed that government expenditure causes growth. On the other hand the growth of GDP does not cause expansion of government expenditure. The authors concluded that judging from the Causality Test, Keynesian hypothesis exert more influence on growth than Wagners Law in US.

Hence, this study can be linked to the Keynesian view since government intervention in the economies of SSA countries through massive increase of public spending on agriculture, is expected to expand aggregate demand in the economy and enhance economic growth in the region.

Hence, this study examines the effect of government expenditure on economic growth in the SSA countries of Nigeria, South Africa, and Ghana through government financing of agricultural productivity

\section{METHODOLOGY}

The ex-post facto research design is used. The expost-facto design will be used because the data type for this study are already documented by highly research- based institutions like the World Bank, IMF, OECD, CBN, among others. Thus, researchers have to rely on such official publications for valid academic exercise.

The study is based on time series data generated from secondary sources. The data for the study was collected from the World Bank Development Indicator (WDI) Online Database, which provides the detailed information about the Gross Domestic Product (GDP) growth rates variables of government agricultural financing for the selected Sub-Saharan African (SSA) countries. The data covers annual time series for the period $(1980-2013)$. The time period was chosen because some of the variables to be used in this study started from 1980 for most of the countries selected for the study. Hence, the selection of 1980 to 2013 as time frames. The countries selected are in the same homogenous class (middleincome Sub-Sahara Africa).

The variables used in this study include economic growth (as the dependent variable) and the explanatory variables of government agricultural investment, which constitute the objectives of this study. Since all the data for the variables were collected from the World Development Indicator (WDI) on-line database, the description to these variables is in line with those of the WDI metadata indicator source notes 2013. 
The model developed and used in this study hinges on the Keynesian proposition that government expenditure is an exogenous variable that propels economic growth. The function indicates that government expenditure on agriculture can have positive effect on GDP. This postulation was adapted from the models as used in previous studies such as in Musaba, Chilonda and Mmathaya (2013).

$\mathrm{GDP}=\mathrm{f}(\mathrm{ARMI}, \mathrm{AMACH}, \mathrm{RIR})$

Where:

GDP = the growth rate of the GDP at current market prices. It is the dependent variables.

ARMI = Agricultural Raw Materials Imports as a percentage (\%) of merchandise imports.

AMACH = Agricultural Machinery measured by tractors per $100 \mathrm{sq}$. km of arable land.

$\mathrm{RIR}=$ Real interest rate (\%) is the lending interest rate adjusted for inflation as measured by the GDP deflator. It is used as control variables for reaction of to economic activities of the government.

The relationship can be explicitly formulated into an econometric equation thus:

$\mathrm{GDP}=\mathrm{c}_{0}+\mathrm{c}_{1} \mathrm{ARMI}+\mathrm{c}_{2} \mathrm{AMACH}+\mathrm{c}_{3} \mathrm{RIR}+\mu$

Where $c_{0}$ is a constant or intercept. $c_{1}, c_{2}$ and $c_{3}$ are the coefficients of the explanatory variables. $\mu$ is stochastic error term.

Econometric techniques were used for data analysis namely; the unit root, co integration, and vector error correction model. Unit root test is used to test for the stationarity of the time series data in order to eliminate statistically deviated results in the time series analysis, and to use only stationary time series since economic time series often have non-stationary character (Sirucek 2012), The study adopted the Augmented Dickey-Fuller (ADF) (Dickey and Fuller, 1979) and the Phillips-Perron (PP) (Phillips and Peron, 1988) tests for the unit root analysis. Both techniques were used so that they can validate the result of each other.

When the results obtained from the unit root test confirm that all the variables used are stationary, a co -integration test is performed to ascertain the presence or otherwise of co-integration between the series of the same order of integration through forming a cointegration equation. This, tests for the existence of long-run relationship between dependent and independent variables. The Johansen (1991) cointegration technique was adopted to determine the order of integration.

If co-integration is found to exist, error correction mechanism is constructed to model dynamic relationship.The error correction model is designed to capture the short-run deviations that might have occurred in estimating the long-run co-integrating equation. The purpose of error correction model is to indicate the speed of adjustment from short run equilibrium to the long run equilibrium state. The error correction model is as follows:

$$
\Delta Y_{t}=\emptyset_{0}+\sum_{i=1}^{p-1} \emptyset_{i} \Delta Y_{t-1}+E C_{t-1}+\mu
$$

Where

ECt-1 indicates the error-correction term.

The VECM provides a means whereby a proportion of the disequilibrium in the short run is corrected in the long run; thus, error correction mechanism is a means to reconcile the short-run and long-run behaviours of the variables (Gujarati, 2003). The size of the error correction term indicates the speed of adjustment of any disequilibrium towards a long run equilibrium state. However, the greater the coefficient of the parameter, the higher the speed of the adjustment of the model from short run equilibrium to the long run equilibrium state

\section{DATA PRESENTATION, ANALYSIS AND INTERPRETATION OF RESULTS}

\section{Unit Root Test}

The Augmented Dickey-Fuller (ADF) and the Phillips and Perron (PP) tests are conducted on the variables, to determine whether they are stationary or nonstationary series. The two tests were employed to reinforce one another, to ensure their robustness and boost confidence in their reliability. The tested null hypotheses for both unit root tests are to determine the presence of a unit root.

\section{Decision Rule:}

Reject the null hypothesis when the test statistical value is less than the critical value. Otherwise, accept 
and test at higher difference (1 or 2 ). The significance level for the analysis is at $5 \%$.
The tests are done at levels and first difference and presented in Tables 1 for variables on Nigeria, South Africa and Ghana respectively.

Table 1: The Unit Root Test Results for the Selected Variables in Nigeria

\begin{tabular}{|c|c|c|c|c|c|c|}
\hline \multirow{2}{*}{\multicolumn{2}{|c|}{ VARIABLES }} & \multicolumn{2}{|c|}{ Levels } & \multicolumn{2}{|c|}{ First Difference } & \multirow{2}{*}{$\begin{array}{l}\text { Order of } \\
\text { Integration }\end{array}$} \\
\hline & & ADF & $\mathbf{P P}$ & ADF & $\mathbf{P P}$ & \\
\hline & & \multicolumn{5}{|c|}{ NIGERIA } \\
\hline \multicolumn{2}{|l|}{ GDP } & $-3.47^{* *}$ & $-4.07^{*}$ & - & - & $1(0)$ \\
\hline \multicolumn{2}{|l|}{ ARMI } & $-4.13^{*}$ & $-5.39 *$ & - & - & $1(0)$ \\
\hline \multicolumn{2}{|c|}{ AMACH } & -0.77 & -0.88 & $-4.34^{*}$ & $-4.63^{*}$ & $1(1)$ \\
\hline \multicolumn{2}{|l|}{$\overline{\text { RIR }}$} & $-3.56^{* *}$ & $-4.86^{*}$ & - & - & $1(0)$ \\
\hline & & \multicolumn{5}{|c|}{ SOUTH AFRICA } \\
\hline \multicolumn{2}{|l|}{ GDP } & $-3.90^{*}$ & $-4.07^{*}$ & - & - & $1(0)$ \\
\hline \multicolumn{2}{|l|}{ ARMI } & -0.69 & -1.01 & $-5.40^{*}$ & $-5.52 *$ & $1(1)$ \\
\hline \multicolumn{2}{|c|}{ AMACH } & -1.87 & -1.41 & -2.54 & -2.72 & $1(2)$ \\
\hline \multicolumn{2}{|l|}{ RIR } & $-3.58^{* *}$ & $-5.00 *$ & - & - & $1(0)$ \\
\hline \multirow{2}{*}{\multicolumn{2}{|c|}{ GDP }} & \multicolumn{5}{|c|}{ GHANA } \\
\hline & & $-3.17 * *$ & -2.67 & $-6.58^{*}$ & $-7.41^{*}$ & $1(1)$ \\
\hline \multicolumn{2}{|l|}{ ARMI } & -2.44 & -2.72 & $-4.35 *$ & $-6.38^{*}$ & $1(1)$ \\
\hline \multicolumn{2}{|c|}{ AMACH } & -2.49 & -2.29 & $-3.86^{*}$ & $-4.47 *$ & $1(1)$ \\
\hline \multicolumn{2}{|l|}{$\overline{\text { RIR }}$} & $-4.79 *$ & $-7.14^{*}$ & - & - & $1(0)$ \\
\hline \multirow{3}{*}{$\begin{array}{l}\text { Critical } \\
\text { Values }\end{array}$} & $1 \%$ & -3.6496 & -3.6422 & -3.6576 & -3.6496 & \\
\hline & $5 \%$ & -2.9558 & -2.9527 & -2.9591 & -2.9558 & \\
\hline & $10 \% \%$ & -2.6164 & -2.6148 & -2.6181 & -2.6164 & \\
\hline
\end{tabular}

The results on Table 1 indicate that RIR is stationary at level in all the three economies of Nigeria, South Africa and Ghana. However, ARMI is stationary at level in Nigeria and stationary at first differences in South African and Ghana. AMACH is stationary at first difference in Nigeria and Ghana but at second difference in South Africa. Finally, the GDP is stationary at level in Nigerian and South Africa but stationary at first difference in Ghana. The results show that majority of the variables are stationary at levels in Nigeria and South Africa, and at first difference in Ghana.

\section{Tests for Co-integration}

This study adopts Johansen co-integration test (Johansen, 1991). A co-integration test is carried out to determine the long-run relationship between the dependent and independent variables. Co-integration of two or more time series suggests that there is long run equilibrium (relationship) between them (Gujarati \& Porter, 2009).

Decision Rule: The decision rule is to reject the null hypothesis if the value of the Likelihood Ratio is greater than the Critical Value. Otherwise, we do not reject.

Table 2: Test of Co-integration among Variables of Government Financing of Agricultureand Economic Growth in Nigeria, South Africa and Ghana

\begin{tabular}{|l|l|l|l|l|l|l|l|l|}
\hline Nigeria & \multicolumn{3}{|l|}{ South Africa } & Ghana \\
\hline $\begin{array}{l}\text { Likelihood } \\
\text { Ratio }\end{array}$ & $\begin{array}{l}5 \% \\
\text { Critical } \\
\text { Value }\end{array}$ & $\begin{array}{l}1 \% \\
\text { Critical } \\
\text { Value }\end{array}$ & $\begin{array}{l}\text { Likelihood } \\
\text { Ratio }\end{array}$ & $\begin{array}{l}5 \% \\
\text { Critical } \\
\text { Value }\end{array}$ & $\begin{array}{l}1 \% \\
\text { Critical } \\
\text { Value }\end{array}$ & $\begin{array}{l}\text { Likelihood } \\
\text { Ratio }\end{array}$ & $\begin{array}{l}5 \% \\
\text { Critical } \\
\text { Value }\end{array}$ & $\begin{array}{l}1 \% \\
\text { Critical } \\
\text { Value }\end{array}$ \\
\hline $\mathbf{5 2 . 2 6 7 5 *}$ & 47.21 & 54.46 & $59.5183^{* *}$ & 47.21 & 54.46 & $60.4325^{* *}$ & 47.21 & 54.46 \\
\hline $\mathbf{2 8 . 8 4 7 5}$ & 29.68 & 35.65 & $34.7370^{*}$ & 29.68 & 35.65 & $29.7045^{*}$ & 29.68 & 35.65 \\
\hline $\mathbf{1 3 . 6 0 6 7}$ & 15.41 & 20.04 & 14.6627 & 15.41 & 20.04 & 14.5225 & 15.41 & 20.04 \\
\hline $\mathbf{0 . 1 4 4 0 7}$ & 3.76 & 6.65 & $4.4185^{*}$ & 3.76 & 6.65 & $5.5496^{*}$ & 3.76 & 6.65 \\
\hline
\end{tabular}

$*(* *)$ denotes rejection of the hypothes is at $5 \%(1 \%)$ significance level 
Test assumption: Linear deterministic trend in the data Series: GDP GFCOM LNGFPOW LNGFRAIL

The results of the co-integration test for long run relationship between government financing of agriculture and economic growth for Nigeria, South Africa and Ghana are presented on Table 2.The results show one (1) cointegrating equation for Nigeria, and two cointegrating equations for South Africa and Ghana respectively. It becomes necessary to reject the null hypothesis of no co-integration and conclude that there is the existence of long-run relationship among the variables in Nigeria, South Africa and Ghana respectively. This implies that government agricultural financing and economic growth have long run relationship in SSA

\section{Vector Error Correction}

Since the results above reveal the existence of co-integration among the variables of the models, error correction models (ECM) are required to determine the short run dynamism of the relationships. For theoretical meaningfulness, the coefficient of the error term should be negative and range between zero and one in absolute term (Ogundipe \&Oluwatobi, 2014). The error-correction term to be estimated represents the speed of adjustment to equilibrium trends.

The values in bracket are the standard errors while the values in parentheses are the t-statistics (see Tables 3). The ECM $\mathrm{t}_{\mathrm{t}-1}$ is the coefficients of the lag dependent variables in their first difference. The decision rule is to accept as statistically significant, when the t-statistics is greater than 2.0. This criterion is described as rule of the thumb in Onuorah and Akujuobi (2012). The results of the VECM for each model by country are presented as below. The presentation format was adapted from the works of Oluwatobi and Ogunrinola (2011); and Ogundipe andOluwatobi (2014).Equally, the nature of the long run relationship that emerged from cointegration test is examined. The contributions of the coefficients (variables) in each model were interpreted and its significance tested at 5\% level, as adapted from Onuorah and Akujuobi (2012).

Table 3: Short-run Vector Error Correction (VEC) test results on Government Agricultural Financing and Economic Growth and Cointegrating equation Coefficients for Nigeria, South Africa and Ghana.

\begin{tabular}{|c|c|c|c|c|}
\hline \multicolumn{5}{|c|}{ Vector Error Correction Model for Nigeria } \\
\hline $\begin{array}{c}\text { Error } \\
\text { Correction: }\end{array}$ & D(GDP) & $\mathrm{D}(\mathrm{ARMI})$ & $\mathrm{D}(\mathrm{AMACH})$ & $\mathrm{D}(\mathrm{RIR})$ \\
\hline \multirow[t]{3}{*}{ CointEq1 } & 0.003715 & -0.003416 & 0.000106 & 0.026566 \\
\hline & $(0.00498)$ & $(0.00079)$ & $(0.00018)$ & $(0.01920)$ \\
\hline & {$[0.74610]$} & {$[-4.30761]$} & {$[0.57271]$} & [1.38365] \\
\hline \multicolumn{5}{|c|}{ Vector Error Correction Model for South Africa } \\
\hline $\begin{array}{c}\text { Error } \\
\text { Correction: }\end{array}$ & D(GDP) & D(ARMI) & D(AMACH) & $\mathrm{D}$ (RIR) \\
\hline \multirow[t]{3}{*}{ CointEq1 } & -0.650011 & -0.067506 & 0.469241 & 0.698960 \\
\hline & $(0.34341)$ & $(0.02559)$ & $(0.76628)$ & $(0.45755)$ \\
\hline & {$[-1.89279]$} & {$[-2.63771]$} & {$[0.61236]$} & {$[1.52760]$} \\
\hline \multicolumn{5}{|c|}{ Vector Error Correction Model for Ghana } \\
\hline $\begin{array}{c}\text { Error } \\
\text { Correction: }\end{array}$ & D(GDP) & D(ARMI) & D(AMACH) & $\mathrm{D}$ (RIR) \\
\hline \multirow[t]{3}{*}{ CointEq1 } & -0.559900 & -0.020814 & 0.050826 & 2.340052 \\
\hline & $(0.14849)$ & $(0.02997)$ & $(0.03173)$ & $(0.99452)$ \\
\hline & {$[-3.77062]$} & {$[-0.69457]$} & [1.60201] & [2.35295] \\
\hline
\end{tabular}

Cointegrating Equation for Nigeria

\begin{tabular}{|c|c|c|c|c|}
\hline GDP $=$ & -3.6824 & +2.8862 ARMI & +0.6010 AMACH & -0.8641 RIR \\
\hline & & $(2510.47)$ & $(74.3915)$ & $(75.5476)$ \\
\hline & & {$[0.11497]$} & {$[0.08079]$} & {$[-0.11438]$} \\
\hline
\end{tabular}


International Journal of Trend in Scientific Research and Development (IJTSRD) ISSN: 2456-6470

Cointegrating Equation for South Africa

\begin{tabular}{|c|c|c|c|c|}
\hline GDP $=$ & -3.7907 & -0.1393ARMI & +0.0162AMACH & $+0.0854 \mathrm{RIR}$ \\
\hline & & (1.10575) & $(0.01815)$ & (0.09922) \\
\hline & & {$[-0.12603]$} & [0.89532] & [0.86134] \\
\hline
\end{tabular}

Cointegrating Equation for Ghana

\begin{tabular}{|c|c|c|c|c|}
\hline GDP $=$ & -10.4752 & +0.0341ARMI & +0.2697 AMACH & -0.2419RIR \\
\hline & & $(0.83591)$ & $(0.26887)$ & $(0.05561)$ \\
\hline & & [0.04082] & [1.00319] & {$[-4.35119 *]$} \\
\hline
\end{tabular}

NB: Standard errors in bracket \& t-statistics in parentheses

Table 3 was used to examine the short run dynamism of the Government Agricultural Financing and Economic Growth Model as well as the nature of the relationship that exist in the model. The analyses were performed for variables in Nigeria, South Africa and Ghana. In line with the co-integration results, the VEC was performed at one year lag interval for Nigeria, two years for South Africa and one year lag internals for Ghana.

The equation for co-integration in Nigeria indicates that Agricultural Raw Materials Imports (2.8862ARMI) and Agricultural Machinery (0.6010AMACH) have positive relationship with GDP while real interest rate (-0.8641RIR) has negative relationship with GDP. The results means that a one percent rise in ARMI led to about $289 \%$ in GDP over the periods under study and percent rise in AMACH had brought about 60.1\%increase in GDP growth while RIR resulted in about $86.4 \%$ shortfall in GDP. The results further showed that the t-statistics indicate no significant long run effect for the three coefficients (ARMI, AMCH and RIR). VEC result on Nigeria indicates that the model has negative sign; also the magnitude of the error correction term coefficient lies between zero and one. This indicates about $0.37 \%$ (0.003715) short run disequilibrium adjustment to long run equilibrium each year. This result is not statistically significant (t-value $<2$ ). Thus, the adjustment to disequilibrium is not significant for agricultural financing components to converge to equilibrium in the long run. The result thus indicates that government agricultural financing has no significant short run effect on economic growth in Nigeria.

In South Africa, co-integration equation indicates Agricultural Raw Materials Imports (-0.139361 ARMI) has negative effect on GDP. On the other hand, Agricultural Machinery (0.016247 AMACH) and Real Interest Rate (0.085460 RIR) have positive relationship with GDP. The results shows that a percentage increase in agricultural raw materials imports results in $13.9 \%$ fall in GDP; a percentage increase in agricultural machinery leads to about $1.6 \%$ improvement in GDP and a percentage increase in real interest rate leads to $8.5 \%$ rise in GDP. The tstatistics of the coefficients, for the variables (ARMI, AMCH and RIR) indicate that Agricultural Raw Materials Imports (t-value < 2), Agricultural Machinery (t-value $<2$ ), and Real Interest Rate (tvalue $<2$ ) do not have significant effect on GDP. More so, the result for South Africa is showed an error correction term that is within the expected bound (between 0 and 1) and possess the expected negative sign. The coefficient indicates about 65\% (-0.650011) adjustment of the drift from the long-run equilibrium value can be restored within a two-year period. This coefficient is not statistically significant ( $t$-value $<2$ ), thus we conclude that government agricultural financing has not significant short run effect on economic growth in South Africa.

In Ghana however, the co-integrating equation indicates that Agricultural Raw Materials Imports (0.034126 ARMI) and Agricultural Machinery (0.269729 AMACH) have positive effect while Real Interest Rate ( -0.241986 RIR) has negative effect on GDP. The results show that a percentage increase in Agricultural Raw Materials Imports leads to 3.41\% increase in GDP; a percentage increase in Agricultural Machinery results in about $26.9 \%$ increase in GDP. On the contrary, a percentage rise in real interest rate causes about $24 \%$ fall in the GDP of Ghana. The tstatistics of the coefficients, for the variables (ARMI, AMACH and RIR) indicate that Agricultural Raw Materials Imports (t-value < 2), Agricultural Machinery (t-value $<2$ ) do not have significant effect on GDP while Real Interest Rate (t-value > 2) has 
significant negative effect on GDP. However, the error correction term for Ghana, the error correction analysis was performed at one lag internal. The coefficient is rightly signed and shows that there is an annual speed of adjustment to the long-run equilibrium value is about 56\% (-0.559900), statistically significant ( $t-$ value $>2$ ). The result thus indicates that government agricultural financing has significant short run effect on economic growth in Ghana.

On the overall, the result of the error correction term indicates significant adjustment speed for short run disequilibrium to converge to long run equilibrium at about 56\% in Ghana. However, there is no significant adjustment to long run equilibrium in Nigeria and South. Since, greater number of the examined sample (Nigeria and South Africa) has no significant adjustment speed to long run disequilibrium, we conclude that there is no significant short run dynamism for government agricultural financing and economic growth in SSA.

\section{Discussion of Findings}

The results indicate that government financing of agriculture has no significant positive effect on economic growth in any of the three selected SSA countries of Nigeria, South Africa and Ghana. Rather, it is negatively insignificant with growth in two countries, Nigeria and South Africa.

The result further indicates that Agricultural Machinery (AMACH) has insignificant positive effect with economic growth in Nigeria, South Africa and Ghana while Agriculture Raw Material Import (ARMI) is insignificant positive effect on economic growth only in Nigeria and Ghana but has insignificant negative effect in South Africa. However, real interest rate (RIR) has negative effect in Nigeria and Ghana but positive effect in South Africa. Therefore, we conclude that agriculture financing has insignificant positive effect on economic growth in Nigeria, South Africa and Ghana.

Agriculture financing does not seem to have adequately contributed to growth in South African economy; possibly, because of the aridity of the soil such that only $13.5 \%$ of the land can be used for crop production and only $3 \%$ out of the $13 \%$ is considered high potential land (Mohamed, 2000). Mohamed further advanced that farms attacks and negative effect of climate change coupled with increased foreign competition among others, equally contributed. No wonder agriculture contributed only an insignificant proportions of $2.6 \%$ to economic growth (i.e. GDP) in South Africa (www.fao.org.docrep/w518eo6htm, retrieved Feb. 21, 2015); as against $21.3 \%$ in Ghana (www.worldfolio.co.uk/region/africa/Ghana...) and 26.8\% in Nigeria (http://allafrica.com/stories/201405160659.htm, retrieved Feb., 21, 2015).

However, generally, the findings disagrees with theoretical postulations that agricultural investment enhances agricultural productivity and promotes economic growth especially in Africa. This result is inconsistent with Fan and Rao (2003) and Udoh (2011) which concluded that government spending on agriculture in Africa strongly promotes economic growth. It also disagrees with Nchuchuwe and Adejuwon (2012) which affirms immense contribution of African economy. This result, however, agrees with Loto (2011) which found significant negative relationship between growth and expenditure on agriculture in the short-run.

The VECM indicate that government agricultural financing in Nigeria does not have the potential $(0.4 \%)$ to restore long run disequilibrium in the economy; South Africa does not adjust significantly at $65 \%$ to restore long run disequilibrium in the economy and Ghana economy adjusts significantly at $56 \%$ to restore long run disequilibrium in the economy. The study thus concludes that agricultural financing policy is effective only in Ghana. This implies that agricultural financing may not have been an effective policy tool for stabilizing the economies of Nigeria and South Africa. The possible reasons may be attributed; to many years of mismanagement, poorly conceived government policy, neglect and lack of basic infrastructure in the sector in Nigeria, (http://allafrica.com/stories/ 201405160659.htlm). Also it could be due to aridity of soil in South Africa coupled with farm attcks,(Mohamed, 2000), among other factors.

\section{CONCLUSION AND RECOMMENDATIONS}

By means of ECM approach, the study investigated the unit roots of the variables and then conducted cointegration and error correction test on the variables of the study and the findings are presented based on the hypothesis. The cointegration test results indicate that none of the variables of agricultural financing 
(ARMI, AMACH, \& RIR), show positive significant effect on growth in Nigeria, South Africa and Ghana, but rather insignificant positive effect (weak influence) on GDP growth. The weak effect of government financing of agriculture on growth in Nigeria for instance, may be probably due to the many decades of mismanagement of the agric sector, and poorly conceived government policies, neglect, and lack of basic infrastructures as well as land tenure system. (www.fao.org.docrep/w518eo6htm), in South Africa, high degree of aridity of farm land, the violent crime of farm attacks, negative effect of climate change , adverse effect of foreign competition from China and India, which has helped to decline exports of some sub-sectors(like food, textile and paper in South Africa). In Ghana, with irrigation almost nonexistent, Ghana agriculture still depends on weather, and coupled with the problem of limited use of modern techniques, hence agriculture productivity increase is gradual (Wikipedia).

Finally, overall, the VECM test indicate that in addition to the weak effects on economic growth, exhibited by the agricultural variables in SSA countries, only the economy of Ghana has significant adjustment speed of $56 \%$ for short run disequilibrium to converge to long run equilibrium. This shows that government financing of agriculture in SSA has not been effective and a lot need to be done to revamp agriculture in SSA.

\section{RECOMMENDATIONS}

Based on the observed peculiarities in each selected country, the study recommends as follows;

In Nigeria, the study recommends that government puts in place, a more comprehensive and consistent agriculture policy that should accommodate genuine rural farmers, through provision of modern agricultureequipment like tractors, and easy access to farm credits by specialized agricultural development institutions like Bank of Agriculture(BOA), provision of adequate infrastructural facilities and services, like railways, paved roads to rural hinterland and other transport facilities. Farmers and agricultural investment should also be encouraged by placing a ban on the importation of some agricultural products especially those that can be effectively produced locally such as, poultry products, rice and other grains.
In South Africa, for agriculture to achieve the desired growth effect on the economy, the government must look into and find solutions to the identified problems of the sector which include among others, high degree of aridity of farm land (through irrigation), the violent crime of farm attacks(upgrading security network) , negative effect of climate change (use of fertilizers), encouraging export growth to neutralize the adverse effect of foreign competition from China and India, which has helped to decline exports of some subsectors(like food, textile and paper in South Africa) to enhance the desired economic growth in those countries, (Wikipedia accessed March 10, 2014).

In Ghana, with irrigation almost non- existent, Ghana agriculture still depends on weather, and coupled with the problem of limited use of modern techniques, productivity increase is gradual (Wikipedia). And since in Ghana, ARMI and AMACH insignificantly cause growth, more budgetary allocations should be provided for importation of ARMI and AMACH to improve agricultural productivity, increase export and eventual GDP growth (Wikipedia accessed March 10, 2014). Secondly, since RIR decreases growth in Ghana, it is recommended that monetary authorities should decrease the interest rate gap between lending and borrowing rates to encourage investment in agriculture. Equally it is recommended that Ghana continue to access more international loans to further assist development of agriculture.

\section{REFERENCES}

1) Abdullah, H. (2000). The Relationship between Government Expenditure and Economic Growth in Saudi Arabia. Journal of Administrative Science 12(2), 173-191.

2) Abu, N. \& Abdullahi, U. (2010). Government Expenditure and Economic Growth in Nigeria, 1970-2008: A Disaggregated Analysis. Business and Economic Journal, Volume 2010 June: BEJ-4, 1-11. Retrieved on March 8, 2011 from http:/astonjournals.com/bej.

3) Al-Yousif, Y. (2000). Does Government Expenditure Inhibit or Promote Economic Growth? Some Empirical Evidence from Saudi Arabia' Indian Economic Journal, 48(1), 22 - 34.

4) Anderson, E.P. de Renzio \& Levy, S. (2006). The Role of Public Investments in Poverty Reduction; 
Theories, Evidence, and Methods. Working Paper 263. London: Overseas Development Institute.

5) Allen, S.M. \& Quaim, M. (2012). Agricultural Productivity and Public Expenditures in SubSaharan Africa. IFPRI Discussion Paper 01173, April. West and Central Office.

6) Barro, R. J. (1990). Government Spending in a Simple Model of Endogenous Growth, Journal of Political Economy, 98(5), $103-125$.

7) Cheng, B. S. \& Lai, T. W.(1997), Government Expenditure and Economic Growth in South Korea: A VAR Approach, Journal of Economic Development, 22(1), 1997 June.

8) Cooray, A. (2009). A Comparative Economic Studies 51(3), 401-418. Retrieved from http://www.ingentaconnect.com/content/pal/ces;js essionid $=\mathrm{q} / \mathrm{g} 8 / \mathrm{gkzfvms}$. alice

9) Diamond, J.(1989). Government Expenditure and Economic Growth: An Empirical Investigation. IMF Working Paper 89, 45, Washington D.C.

10) Dickey, D. \&Fuller W. (1979). Distribution of the Estimators for Autoregressive Time Series with a Unit Root. Journal of American Statistical Association, 74, 427 - 431.

11) Ebiringa, O. E. \& Charles-Anyaogu, N. B. (2012). The Impact of Government Sectoral Expenditure on the Economic Growth of Nigeria.

12) Engen, E.M.\& Skinner, J. (1992). Fiscal Policy and Economic Growth. National Bureau of Economic Research NBER Working Paper No. 4223

13) Folster, S. \& Henrekson, M. (1999). Growth Effect of Government Expenditure and Taxation in Rich Countries. European Economic Review, 45, 1501-1520

14) Grier, K. B. \& Tullock, G. (1989). An Empirical Analysis of Cross-National Economic Growth, 1951-1980, Journal of Monetary Economics, 24, 259-276.

15) Gujarati, N. D. (2003). Basic Econometrics. 4th Edition, Tata: McGraw-Hill Publishing

16) Johansen, S. (1991). Cointegration and Hypothes is Testing of Cointegration Vectors in Gaussian Vector Autoregressive Models, Econometrica, 59(6):1551-1580.

17) International Development Association, IDA (2009). Agriculture: An Engine of Growth and Poverty Reduction. Available on the internet at, http://www.worldbank.org/ida.

18) Kormendi, R. C. \& Meguire, P. G. (1985). Macroeconomic Determinants of Growth: Cross-
Country Study, Journal of Monetary Economics, 16, 141-163

19) Landau, D. L. (1986). Government and Economic Growth in the Less Developed Countries: An Empirical Study for 1960-88, Economic Development and Cultural Change, 35-75.

20) Levine, R. \& Renelt, D. (1992). A Sensitivity Analysis of Cross-Country Growth Regression, American Economic Review, 82(4), 942-963.

21) Loto, M. A. (2011). Impact of Government Sectoral Expenditure on Economic Growth. Journal of Economics and International Finance, 3(11), 646-652. Retrieved from http://www.academicjournals.org/JEIF.

22) Lui Chih, H. L., Hsu, C. \&Younis, M. Z.(2008). The Association between Government Expenditure and Economic Growth: The Granger Causality Test of the US Data, 1974-2002. Journal of Public Budgeting, Accounting and Financial Management, 20(4), 439-452.

23) McGuire, M. C. (1978). A method for estimating the effect of a subsidy on the receiver's resource constraints: With an application to the US local governments (1964-71). Journal of Public Economics, 10(10), 366-369

24) McGuire, M. C. (1987). Foreign Assistance, Investment and Defence: A Methodological Study with an Application to Israel (1960-79). Economic Development and Cultural Change, 7; 847-7

25) Morgan, W. B. \& Solarz, J. A. (1994), "'Agricultural Crises in Sub-Saharan Africa: Development Constraints and Policy Problems,', The Geographical Journal 160(1), 57-73.

26) Morgues, T., Bingxin,Y. Fan, S. McBride, L.(2011). The Impact of Public Investment in and for Agriculture: Synthesis of the Existing Evidence. Background Paper for the Food and AgricultureOrganization of the United Nations 2012 State of Food and Agriculture (SOFA) Report on Agricultural Investments. Washington, DC: IFPRI.

27) Nchuchuwe, F. F. \& Adejuwon, K. D. (2012). The Challenges of Agriculture and Rural Development in Africa: The Case of Nigeria. International Journal of Academic Research in Progressive Education and Development, 1(3), 45-61.

28) NEPAD (2011). Comprehensive Africa Agriculture Development Programme. Retrieved on November 4, 2014 from http//nepad-caadp.net 
29) Ram, R. (1986). Government Size and Economic Growth: A New Framework and Some Evidence Cross-Section and Time Series Data. American Economic Review, 76, 191-203.

30) Ram, R. (1996). Government Size and Economic Growth: A New Framework and Some Evidence Cross-Section and Time Series Data. American Economic Review, 76, 191-203.

31) Taban, S. (2010). An Examination of the Government Spending and Economic Growth Nexus for Turkey, using the Bound Test Approach. International Research Journal of Finance and Economies, 48, 78 - 92. Retrieved from http:/www.eurojournals.com/finance.htm

32) Olugbenga, A.O. \&Owoye, O.(2007), Public Expenditure and Economic Growth:New Evidence from OECD Countries.. Retrieved on March 8, 2011 from [http://iaes.confex.com/iaes/Rome_67/techprogra $\mathrm{m} / \mathrm{S} 1888 . H T M$
33) Onwumere, J.U.J (2009). Business and Economic Research Method, Enugu:Vougasen Publishers.

34) Pesaran, H.M., \& Smith, R.J.(1995). Estimating the Long run Relationship from Dynamic Heterogeneous Panels. Journal of Econometrics, 68, 79-113

35) Rennikka, R. \& Svensson, J. (2002). Explaining leakage of funds: Centre for Economic Policy Research. Discussion Paper 3227. Retrieved form www.cepr.org/pubs/dps/Dp3227.asp.

36) Romer, P. (1989). What Determines the Rate of Growth Technological Change, World Bank Working Papers.

37) Romer, P. M. (1990). Endogenous Technical change. Journal of Political Economy, 98, 571 581

38) Wikipedia accessed March 10, 2014

39) World Development Report (WDR) (2008). Agriculture for Development. Available at www.worldbank.org/wdr2008 